\title{
Serum Sodium Level on the Recurrence of Febrile Seizure within the Same Febrile Illness-Experience in a District Level Hospital
}

\author{
M Luthfor Rahman, ${ }^{1}$ Belal Hossain, ${ }^{2}$ Belal Uddin, ${ }^{3}$ Sanaul Haq Mia ${ }^{4}$
}

\begin{abstract}
Introduction: Febrile convulsion is the most common seizure disorder in the pediatric age group. It occurs in $2-5 \%$ of children. A febrile seizure is a seizure accompanied by fever (temperature $100.4^{\circ} \mathrm{F}$ or $38^{\circ} \mathrm{C}$ by any method), without central nervous system infection, that occurs in infants and children 6 through 60 months of age.

Aim: The study was conducted to see the effect of serum sodium level on the recurrence of febrile seizure during the same febrile illness.

Materials and Method: A cross-sectional descriptive study which enrolled 65 children admitted with febrile seizures at $\mathbf{1 0 0}$ bed district hospital, Naogaon. They were divided in to two groups, those with a single seizure and the rest were children with more than one seizures. Serum sodium levels were estimated after stabilization of patients. The probability of recurrent febrile seizures and serum sodium level was analyzed.
\end{abstract}

Results: Hyponatremia (serum sodium $<135 \mathrm{mmol} / \mathrm{l}$ ) was seen in $12(18.5 \%)$ of 65 children and the remaining $81.5 \%$ children had normal serum sodium level (serum sodium $135-145 \mathrm{mmol} / \mathrm{l}$ ). Among the hyponatremia group all children developed more than one seizure during the same febrile episode. The mean serum sodium level in patients with single and recurrent seizure was $138.48 \pm 2.17 \mathrm{mmol} / /$ and $135.27 \pm 3.11 \mathrm{mmol} /(\mathrm{P}<0.001)$. The relationship between the probability of a recurrent seizure and serum sodium level is statistically highly significant.

Conclusion: Estimation of the seum sodium in children with febrile seizures help in deciding for admission in hospital as well as to predict seizure recurrence within the same febrile episode.

Key words: Febrile seizure, recurrent, serum sodium.

TAJ 2019; 32: No-1: 39-45

\section{Introduction}

Febrile convulsion is the most common seizure disorder in the pediatric age group. It occurs in 2$5 \%$ of children. ${ }^{1,2}$ A febrile seizure is a seizure accompanied by fever (temperature $100.4^{\circ} \mathrm{F}$ or $38^{\circ} \mathrm{C}$ by any method), without central nervous system infection, that occurs in infants and children 6 through 60 months of age. ${ }^{3}$ It accounts for about $1 \%$ of all emergency department visits, and about $2 \%$ of children's hospital emergency department visits. ${ }^{4}$ Although most febrile seizures are brief, do not require any specific treatment or work up, and have benign prognosis witnessing such seizures is a terrifying experience for most parents. $^{4-10}$ Evidence suggests having a peak incidence at about 18 months of age, whether the

1 Junior Consultant (Paediatrics), 100 Bed District Hospital, Naogaon.

2 Junior Consultant (Paediatrics), Rajshahi Medical College Hospital.

3 Professor and Head Department of Paediatrics, Rajshahi Medical College.

${ }^{4}$ Professor (on PRL), Department Paediatrics, Rajshahi Medical College. 
child can be neurologically normal or abnormal. ${ }^{11}$ Febrile seizure may be simple or complex. A simple febrile seizure is a primary generalized, usually tonic-clonic, attack associated with fever, lasting for a maximum of $15 \mathrm{~min}$, and not recurrent within a 24-hr period. A complex febrile seizure is more prolonged ( $>15 \mathrm{~min}$ ), is focal, and/or recurs within $24 \mathrm{hr}$.

Though febrile seizures are considered as a genetic disorder but mode of inheritance vary between families and may be multifactorial. Simple febrile seizure does not lower intelligence (i,e cause learning disability) or are associated with increased mortality. ${ }^{12}$ Risk of recurrence in febrile convulsion is $30-40 \%$ and half of these go on to get a second recurrence. ${ }^{13}$ It recurs in approximately $30 \%$ of those experiencing a first episode, in $50 \%$ after 2 or more episodes, and in $50 \%$ of infants younger than 1 yr old at febrile seizure onset. Several factors affect recurrence of febrile seizure occurrence.

Risk factors for recurrence of febrile seizure:

Major:

Age $<1$ year

Duration of fever $<24$ hours

Fever $38-39^{\circ} \mathrm{C}\left(100.4-102.2^{\circ} \mathrm{F}\right)$

Minor:

Family history of febrile seizure

Family history of epilepsy

Complex febrile seizure

Male gender

Daycare

Low serum sodium level at the time of presentation

Having no risk factors carries a recurrence risk of approximately 12\%; 1 risk factor, 25-505;2 risk factors, $50-59 \%$; 3 or more risk factors, $73-100 \%{ }^{14}$

Fever plays an important role in causing disturbances of fluid and electrolyte balance leading to hyponatremia. This hyponatremia is probably due to inappropriate secretion of antidiuretic hormone. ${ }^{15}$ Hyponatremia has been thought to enhance the susceptibility to seizures associated with febrile illness in childhood. Functions of sodium include maintenance of fluid balance, regulation of BP, and normal functions of the nervous system. As Physiology goes, sodium is the dominant extra cellular cation, which determines the fluid movement. Whenever the level of sodium becomes low, it causes excess water to enter the cells. Extra cellular hypoosmolarity causes shift of fluid from intravascular space to intracellular space. Most of the cells has the ability to expand, except for the neuronal cells, because brain is confined to a bony calvarium, where expansion is limited. So, this results in intracerebral edema which causes constant irritation of the neurons, ultimately resulting in seizures. As the sodium level goes down, more is the seizure leading on to recurrence. Conversely, hyponatremia cause more calcium ion influx in neurons, and generates repetitive action potential which will result repetitive seizure initiation.

Convulsions in children generate a huge amount of fear in the parents or caregivers regarding the child's illness. One of the most frequently asked question is the probability of another convulsion during the febrile episode. During routine electrolyte studies in patients with febrile convulsions, some researchers found the serum sodium level to be lower in children with recurrent convulsion within the same febrile illness. 16-18 With this background we conducted this study to assess the role of serum sodium level as an indicator of seizure recurrence within the same febrile episode.

\section{Materials and Methods:}

A cross-sectional descriptive study was done over a period from September 2017 to August 2018 among 65 children with febrile seizures admitted in Paediatric ward, 100 bed district hospital, Naogaon.

Inclusion criteria:

* Children aged 6month to 60 months

* Children with febrile seizures

Exclusion criteria:

* Children with signs of meningitis 
* Children with gastroenteritis

* Children with developmental delay

* Children with neurologic disorders

* Children with a history of afebrile seizures.

Data were collected using preformed questionnaire. Physical and neurological examinations were done as usual. Under all aseptic precaution $2 \mathrm{ml}$ of venous blood were collected and sent for serum sodium estimation after stabilization of patient. Serum electrolytes were evaluated by using Automated Electrolyte Analyzer "Easylyte plus" Medica corporation, USA. Method: Ion selective Electrode machine and data was analyzed by SPSS program and student's " $t$ " test was carried out.

\section{Results:}

There were 65 children with febrile seizures in this study, consisting of 39 boys (60.0\%) and 26 girls (40.0\%) (Fig:I). The age range was from 6 months to 54 months with mean age 21.5 months. Number of patients age group 6-12 month, 13-24 month, 25-36 month, 37-48 month and 49-60 month were 16(24.61\%), 30(46.15\%), 14(21.53\%), 04(6.15\%) and 01(1.53\%) respectively. (Fig:II)

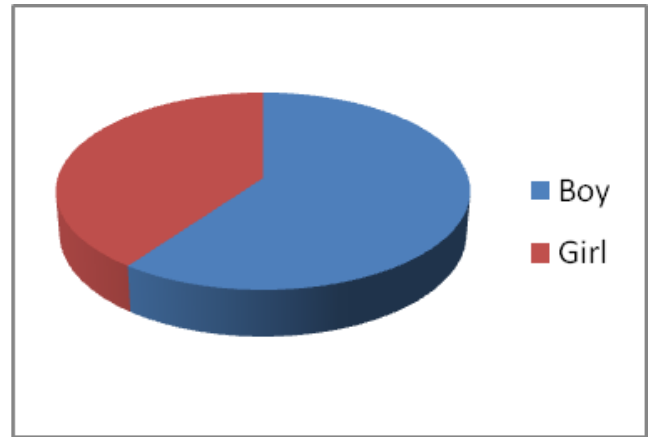

Figure: I

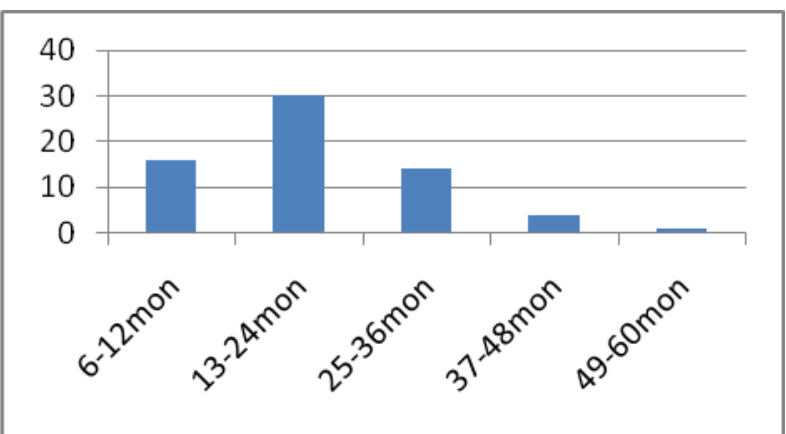

Figure: II

Table-I: Clinical characteristics of the patients $(\mathrm{n}=65)$

Duration of seizure:

15 min or less

More than $15 \mathrm{~min}$

Type of seizure:

Generalized

Focal

Type of febrile seizure:

Simple

Complex

Episode of febrile seizure:

$1^{\text {st }}$ episode

Recurrent episode

Number of seizure:

Single seizure

More than one seizure

(Recurrent)
$51(78.46 \%)$

$14(21.54 \%)$

59(90.8\%)

6(9.2\%)

23(35.4\%)

42(64.6\%)

40(61.5\%)

25(38.5\%)

$33(50.8 \%)$

32(49.2\%)

Table: I showed that seizure persisting for 15 minutes or less were seen in 51(78.46\%) and more than 15 minutes in 14(21.54\%) children. Generalized and focal seizures were seen in 59(90.8\%) and 6(9.2\%) respectively. Simple and complex febrile seizures were identified in 23(35.4\%) and 42(64.6\%) patients 
respectively. Majority (46.15\%) of the patients were between age group 13 month-24 months. Among 65 children $40(61.5 \%)$ had $1^{\text {st }}$ episode and $25(38.5 \%)$ had recurrent episode of febrile seizure during different febrile illness. Single and recurrent seizures were observed in 33(50.8\%) and 32(49.2\%) of patients respectively during the same febrile episode. Twenty-two (33.8\%) patients had a family history of febrile seizures. The mean time interval between onset of fever and onset of seizure was 10.5 hours (SD 10.64).

Table-II: Distribution of respondents by febrile seizure type and mean serum sodium:

$\begin{array}{lll}\text { Febrile seizure } & \begin{array}{l}\text { Mean serum } \\ \text { sodium(mmol/l) }\end{array} & \text { Standard deviation } \\ \text { Simple febrile seizure } & 138.27 & 2.19 \\ \begin{array}{l}\text { Complex febrile } \\ \text { seizure }\end{array} & 136.15 & 3.29 \\ \end{array}$

The mean serum sodium level in simple febrile seizure was $138.27 \pm 2.19 \mathrm{mmol} / \mathrm{l}$ and complex febrile seizure $136.15 \mathrm{mmol} / \mathrm{l} \pm 3.29 \mathrm{mmol} / \mathrm{l}$ (Table II).

Table-III: Distribution of respondent by age group and mean serum sodium level:

$\begin{array}{llll}\text { Age group } & \text { No. of patient } & \begin{array}{l}\text { Mean serum sodium } \\ (\mathrm{mmol} / \mathrm{l})\end{array} & \text { Standard deviation } \\ \begin{array}{l}6 \text { month- } \\ 12 \text { months }\end{array} & 16(24.61 \%) & 136.23 & 2.05 \\ \begin{array}{l}13 \text { month-24 } \\ \text { months }\end{array} & 30(46.15 \%) & 136.99 & 3.35 \\ \begin{array}{l}25 \text { month-36 } \\ \text { months }\end{array} & 14(21.53 \%) & 137.24 & 4.06 \\ \begin{array}{l}37 \text { month-48 } \\ \text { months }\end{array} & 04(6.15 \%) & 137.50 & 0.88 \\ \begin{array}{l}49 \text { month-60 } \\ \text { months }\end{array} & 01(1.53 \%) & 138.00 & 0.00\end{array}$

Mean serum sodium level in age group 6 month-12 months,13 month-24 months, 25 month-36 months, 37 month-48 months and 49 month-60 months were $136.23 \pm 2.05 \mathrm{mmol} / \mathrm{l}, 136.99 \pm 3.35 \mathrm{mmol} / \mathrm{l}$, $137.24 \pm 4.06,137.50 \pm 0.88 \mathrm{mmol} / \mathrm{l}, 138.00 \pm 00 \mathrm{mmol} / \mathrm{l}$ respectively. Majority (46.15\%) of the patients were between age group 13 month-24 months and mean serum sodium level at this age was 136.99 $\pm 3.35 \mathrm{mmol} / \mathrm{l}$.(Table:III).

Table-IV: Distribution of the respondents by sex and mean S. sodium level.

$\begin{array}{llll}\text { Sex } & \text { S. sodium }(\mathrm{mmol} / \mathrm{l}) & \text { Standard deviation } & \text { P value } \\ \text { Boy } & 136.44 & 3.49 & 0.148 \\ \text { Girl } & 137.58 & 2.29 & 0.118\end{array}$


Boys had mean serum sodium level $136.44 \pm 3.49 \mathrm{mmol} / \mathrm{l}$ and girls had mean s. sodium level 137.58 \pm 2.29 $\mathrm{mmol} / \mathrm{l}$. This shows that boys are more prone to develop seizure activity at a relatively lower level of serum sodium than the girls. The association between sex and seizure activity is not statistically significant ( $\mathrm{p}>0.05)$. (Table: IV).

Table-V: Distribution of respondents by number of seizures and mean S. sodium level:

\begin{tabular}{|c|c|c|c|c|}
\hline Number of seizure & Number of patient & S. sodium $(\mathrm{mmol} / \mathrm{l})$ & $\begin{array}{l}\text { Standard } \\
\text { deviation }\end{array}$ & $P$ value \\
\hline Single seizure & $33(50.8 \%)$ & 138.48 & 2.17 & 0.000 \\
\hline $\begin{array}{l}\text { Recurrent(more } \\
\text { than one) seizure }\end{array}$ & $32(49.2)$ & 135.27 & 3.11 & 0.000 \\
\hline
\end{tabular}

The mean serum sodium level in patients with single seizure was $138.48 \pm 2.17 \mathrm{mmol} / \mathrm{l}$ and mean serum sodium level in patients with recurrent seizure was $135.2 \pm 3.11 \mathrm{mmol} / \mathrm{l}$. The difference of mean serum sodium level between single seizure and recurrent seizure was statistically highly significant $(\mathrm{P}<0.001)$. (Table: V)

Table-VI: Distribution of serum sodium and number of seizures:

\begin{tabular}{|c|c|c|c|c|}
\hline \multirow{2}{*}{$\begin{array}{l}\text { Serum sodium } \\
(\mathrm{mmol} / \mathrm{l})\end{array}$} & \multicolumn{2}{|c|}{ Number of seizure } & \multirow[t]{2}{*}{ Total } & \multirow[t]{2}{*}{$\mathrm{P}$ value } \\
\hline & single seizure & $>1$ seizure & & \\
\hline \multirow[t]{2}{*}{$<135.00$} & 0 & 12 & 12 & 0.000 \\
\hline & & $100.0 \%$ & $100.0 \%$ & \\
\hline \multirow[t]{2}{*}{$135-145$} & 33 & 20 & 53 & 0.000 \\
\hline & $62.3 \%$ & $37.7 \%$ & $100 \%$ & \\
\hline
\end{tabular}

Hyponatremia (serum sodium $<135 \mathrm{mmol} / \mathrm{l}$ ) was seen in $12(18.5 \%)$ patient and the rest 53(81.5\%) patient had normal serum sodium level (135.00-145 mmol/l). Among the hyponatremia group all 12(100.0\%) patient developed more than one seizure during the same febrile episode. Among the normal serum sodium level group 33(62.3\%) developed single seizure and 20(37.7\%) patient developed more than one seizure during the same febrile episode. The association between serum sodium level and recurrence of seizure was statistically highly significant $(\mathrm{P}<0.001)$.(Table: VI)

\section{Discussion}

There were 39(60.0\%) boys and 26(40.0\%) girls and boy-girl ratio was 2:1 in our study which is similar to the findings (2.07:1) of Hoque $\mathrm{M}^{19}$ et al. It reveals that febrile convulsion is more common in boys than girls and this is in agreement with the observation of Molla MR. ${ }^{20}$ In this study majority of the children 30(46.15\%) were in age group 13 month-24 months and Molla $\mathrm{MR}^{20}$ found mostly around 20 months of ages. In our study mean age of febrile seizure was 21.5 months which is similar to the finding of 20.9 months found in a study of Deng $\mathrm{CT}^{21}$ et al. The mean duration of fever prior to onset of first seizure in our study was 10.5 hours and it is 16.5 hours in the study of Biswas $\mathrm{R}^{22}$ et al. Seizure lasting for 15 minutes and less in $78.5 \%$ cases and more than 15 minutes in $21.5 \%$ cases in our study, which is close to the findings of Hoque $\mathrm{M}^{19}$ et al ( less than 15 minutes duration in 
83.72\% and more than 15 minutes duration $16.28 \%$ cases) and Bessissco $\mathrm{MS}^{23}$ et al found seizure duration less than 15 minutes in $84.6 \%$ and more than 15 minutes in $15.4 \%$ cases.

We found $61.5 \% 1^{\text {st }}$ episode of febrile seizure and $38.5 \%$ recurrent episode of febrile seizure and this is similar to the results of Biswas $\mathrm{R}^{22}$ et al $(67.5 \%$ and $32.5 \%$ respectively). In our study $49.2 \%$ children developed recurrent seizure during the same febrile illness. This is similar to the findings (48.7\%) of Deng $\mathrm{CT}^{21}$ et al. Generalized and focal seizure were seen in $90.8 \%$ and $9.2 \%$ respectively in this study. This is similar to the findings $(90.0 \%$ and $10.0 \%$ ) of Biswas $\mathrm{R}^{22}$ et al. Twenty-three children (35.4\%) were developed simple febrile seizure which Biswas $\mathrm{R}^{22}$ et al found $61.2 \%$. Distribution of simple and complex febrile seizure varied widely in different studies ${ }^{24}$ which may be due to difference in criteria adopted.

In our study 12(18.5\%) out of 65 children with febrile seizures had serum sodium level $<135$ $\mathrm{mmol} / \mathrm{l}$. This is comparable to the incidence of 18$35 \%$ found in other studies ${ }^{15,25}$.Mean serum sodium levels were lower in those children with complex febrile seizures $(136.15 \pm 3.29 \mathrm{mmol} / \mathrm{l})$ than those with simple febrile seizures (138.27 \pm 2.19$)$. This is similar to the findings of Kiviranta $\mathrm{T}^{16}$ et al $(136.07 \pm 3$. $06 \mathrm{mmol} / \mathrm{l}$ and $137.62 \pm 2.63 \mathrm{mmol} / \mathrm{l}$ in case of complex and simple febrile seizure respectively). Mean serum sodium level in case of single seizure was $138.48 \pm 2.17 \mathrm{mmol} / \mathrm{l}$ and in recurrent seizure $135.27 \pm 3.11 \mathrm{mmol} / \mathrm{l}$ which is similar to the findings of Nadkarni $\mathrm{J}^{26}$ et al $(138.2 \pm 3.7 \mathrm{mmol} / \mathrm{l}$ and $134.3 \pm 3.8 \mathrm{mmol} / \mathrm{l}$ in case of single seizure and recurrent respectively).

\section{Conclusion}

Though estimation of serum electrolytes in febrile seizure is not routinely recommended for the sole purpose of identifying the cause of a simple febrile seizure but it can assist in deciding for hospital admission as well as predicting the risk of recurrence within the same febrile episode.

\section{References}

1. Berg A T, Shinnar S, Hauser W A, Leventhal J M. Predictor of recurrent febrile seizure; a metaanalytic review. J pediatr. 1990; 116: 329-37. 2. Consensus statement febrile seizures. Long term management of children with fever- associate seizures. Pediatrics 1980; 66: 1009-12.

3. Subcommittee on Febrile seizures, Febrile Seizures: Guideline for the Neurodiagnostic Evaluation of the Child With a Simple Febrile Seizure. Pediatrics 2011; 127:389-94.

4. Martindale JL, Goldstein JN, Pallin DJ: Emergency department seizure epidemiology. Emerg Med Clin North Am 2011 Feb, 29(1): 15-27

5. Ducan JS, Shorvon SD, Fish DR (editors). Clinical Epilepsy, First edition. New Delhi: B.I. Churchil Livingstone Pvt. Ltd, 1995. Pp. 74-76.

6. Khan MR. Febrile seizure. Bangladesh Private Medical Practitioners Journal 2003; 9: 30-31.

7. Tsuboi T. Epidemiology of febrile convulsions in children in Japan. Neurology 1984; 34: 175-181.

8. Wallace SJ. Recurrence of febrile convulsions. Arch Dis Child 1974; 49: 763-775.

9. Collins T. Febrile convulsion. Institute of Child Health. Great Ormond Street Hospital for Children. Published in The Times of London, 14 March 2000. pp 89-94.

10. Millichap JG, Millichap JJ. Role of viral infec- tions in the etiology of febrile seizures. PediatrNeurol 2006; 35: 165-72.

11. Shinnar S, \&Glauser TA. Febrile Seizures. J Child Neurol 2002; 17: S44.

12. Vestergaard $M$, Pedersen MG, Ostergaard JR, Pedersen CB, Olsen J, Christensen J. Death in children with febrile seizures: a population-based cohort study. Lancet. 2008 Aug 9. 372 (9637): 45763

13. Vestergaard $M$, Basso $O$, Henriksen TB, Ostergaard JR, Olsen J. Risk factors for febrile convulsions. Epidemiology 2002; 13 (3): 282-7.

14. Mikati M A and Hani A J.Febrile Seizures.In Kleigman RM,Stanton BF, Schor NF. Tweenth edition. Nelson Textbook of Pediatrics. Philadelphia. ELSEVIER, 2016; 2829-2831

15. Rutter N, Smales ORC. Role of routine investigations in children presenting with their first febrile convulsions. Arch Dis Child 1977; 5: 188-91.

16. Kirivanta T, Airaksinen EM. Low sodium levels in serum are associated with subsequent febrile seizures. Acta Paediatr 1995; 84: 1372-4.

17. Millichap JG. Studies in febrile seizures. II. Febrile seizures and the balance of water and electrolytes. Neurology 1960; 10: 312-21. 
18. Hugen CA, Oudesluys-Murphy AM, Hop WC. Serum sodium levels and probability of febrile seizure. Eur J Pediatr 1995; 154 (5): 403-5.

19. Hoque M, Ali CMH, Zaman MS et al. Risk factors for recurrent febrile convulsion. Journals of Bangladesh College of Physicians and Surgeons 2004; 22 (2): 49-52

20. Molla MR. Febrile seizures. Concise Textbook of Pediatrics. Third edition january 2014, Dhaka, Bangladesh, p 857-860.

21. Deng CT, Zulkifli HI, Azizi BHO. Febrile seizure in Malaysian Children: Epidemiology and Clinical Features. Med J Malayasia 1994;

22. Biswas R,Munsi AS, Rahman MM, Begum N, Das RC. Clinical profile of febrile convulsion among admitted children in a tertiary care hospital at
Dhaka city. Northern International Medical college Journal 2015; 7 (1): 101-104

23. Bessissco MS, Elsaid MF, Almula NA et al. Recurrence risk after a first febrile convulsion. Saudi Medical Journal 2001; 22 (3): 254-258.

24. Fallah R, Golestan M. Role of laboratory diagnostic tests in first febrile seizure. J Pediatr Neurol. 2008; 6 (2): 129-132

25. Chiarelli F,De Palma C, Verotti a, Lombardi G,Domizio S.Electrolytic changes during febrile convulsions. Pediatr Med Chir 1985; 7 (2): 249-52

26. Nadkarni J, Binykiya I, Sharma $U$ and Dwivedi R. Role of serum sodium levels in prediction of seizure recurrence within the same febrile illness. Neurology Asia 2011; 16 (3): 195-97 